\title{
CIÊNCIANATURA
}

\section{Water's quality and environmental conditions of the hydric resources in Grajaú-MA}

Fernando Machado Ferreira*, Gleidiany da Costa Moreira, Maria Elizabete Gomes de Sousa Silva, Ana Maria Kellen Santos Silva, Gardjany da Costa Moreira, Jefferson Almeida Rocha e Ionara Nayana Gomes Passos

Universidade Federal do Maranhão-MA, Brasil

\section{Abstract}

Water is the essential element to develop and maintaining life, that's why the adoption of means of conservation of this essential resource is necessary. In Brazil, the ordinance number 2914, fromDecember12th, 2011, of the Ministry Of Health establishes microbiological parameters, which determinate it's quality, verifying it's potability in order not to offer health risks. The research analyzed five samples from two different wells, placed in the same district of Grajau-MA. The physical-chemical conditions were analyzed by the following parameters: Total alkalinity, Chlorides, Total hardness, pH, Iron, Ammonia, Chlorine, Consumed oxygen, Water turbidity and Color and microbiological, by the multiple tubes methodology based on the most likely number (MLN). Followed by seedlings on selective culture means. The results obtained in this research show that the samples of underground water from five analyzed spots do not match the legislation, because they do not fit to the potabilitystandards. This way, new analysis must be made, mainly microbiological and biochemical tests, to, this time on, adopt means that allow a proper treatment to this water that is used by the local communities.

Keywords: Wells; Underground Water; Potability 


\section{Introduction}

Water is an essential element for the development and maintenance of life, but only $3 \%$ of the existent reserves in our planet are constituted by fresh water. From this $3 \%$, only $0,3 \%$ can be used for human consumption, from which $0,01 \%$ comes from superficial origins (rivers and lakes) and 0,29\% from underground origins. Glaciers, steam and deep water tables constitute the other sources of fresh water, which is economically impracticable to explore for the population consumption (BRASIL, 2007).

The polluted water can be sources of transmission of many diseases, caused by pathogenic organisms coming from human and animal feces (BRASIL, 2007). That is why microbiological indicators have been used in order to verify the existence of fecal pollution, mainly the Escherichia coli bacteria, which is the most used fecal contamination indicator microorganism in the world (BARRELL et al., 2002).

The origin of the word pollution is related to the esthetic condition of water that seems to be dirty when the pollution can be visibly noticed. However, the alteration in the quality of the water does not appear only at esthetic characteristics. The apparently clean water can contain pathogenic microorganisms and toxic substances (PAULA, 2009).

Therefore, for the water to be considered potable, microbiological and physical-chemical analyzes must be made in order to verify if it fits the potability standards for human consumption stablished in the country's actual laws (CELLIGOI, 1999).

In Brazil, the actual laws regarded to the water's potability for human consumption and underground water are, respectively, the ordinance number 2914, from December 12 ${ }^{\text {th }}, 2011$, of the Ministry Of Health (BRASIL, 2011) and the ordinance number 396, from April 3 $3^{\text {rd }}, 2008$, of the Conselho Nacional do MeioAmbiente (CONAMA) (BRASIL, 2008).

Nevertheless, in face of this approach, there is a necessity to improve the studies about the potability of water for human consumption. In this context, the present paper intends to show the development of this project, involving high school students from the public education net of the city, during the investigative activity of analyses of water's quality. In this project, the students are going to participate of the analyses, since the collect in the spots, to the conclusion of the results. The orientation for the project will come from the authors of the referred project and technics responsible for the laboratory of Chemistry and Biology of UFMA.

The distribution of water to neighborhood residents in the vicinity of the university has its origins in the artesian well, perforated in the district itself, and the distribution of water in the campus also comes from an artesian well, perforated in the campus itself.

The control of the water intended to human consumption, since the capitation to the distribution systems (reservoirs, nets), is normally made by the company responsible for the local sanitation and monitored by the Health Secretary or similar organs.

The purpose of requiring water's quality is the protection of the health of the worked district residents and of the academic community of UFMA, Grajaú Campus, and the preservation of hydric resources. The water is essential for life's maintenance. The protection against contaminations on water supply is the first defense line (DAHI, 1992). Almost invariably, the best method to guarantee proper water for consumption consists in ways of protections, avoiding contaminations from animal and human feces, that can contain a great variety of bacteria, virus, protozoa and helminths. Failures in the protection and the effective treatment expose the community to risks of intestinal diseases and other infectious illnesses (HELLER, 1998).

The main biological agents discovered in the contaminated water are the pathogenic bacteria, the virus and parasites. The pathogenic bacteria observed in the water and/or food constitute one of the main sources of morbidity in our mean.

On the development of the work, the investigative approachwill be utilized. According to Freire 2009, this method of working is basically intended to the mobilization of the students in order to create hypothesis, asks, take decisions and make them to stay on permanent thinking exercise.

The teaching by investigation can be described as a facilitator of the promotion of scientific literature, the development of competences and the relations with Science, Technology, Society and Environment (FREIRE, 2009).

However, it is important to point that the man cannot see the nature as an infinite source of resources that could be intensely devastated in order to satisfy the necessity of consume which could be attended rationally, preserving fauna, flora, water and precious sources of raw material.

This research aims to evaluate the microbiological and physical-chemical quality of the water, in Grajaú-MA.

\section{Methodology}

\subsection{Area of study}

The study was developed in the city of Grajaú, Maranhão, placed at the center-south region of the state. It has $8.842,782$ $\mathrm{km}^{2}$ of area and is $560 \mathrm{~km}$ away from the capital São Luís.

The collects were made in July 2017, in two wells of the city. One of them supplies the population of a part of the town and the other one, the Federal University of Maranhão - UFMA, Campus Grajaú. From these two wells, five samples were taken:

A1 = Reservoir of the town's supply unity; 
A2 $=$ Well of the town's supply unity;

A3 = Residence;

A4 = Well in UFMA;

A5 = Drinking fountain of UFMA;

The procedure of collecting was accomplished by observing the techniques of samples collection in the practical manual of water analyses of FUNASA (2013) for collecting in wells.

\subsection{Sample}

The samples of water were obtained by collection made according technical recommendations and with asepsis.

\subsection{Instruments and Procedure of Data Collection}

The work started with the descriptive and exploratory part of the research, followed by the collections. These ones occurred in June 2017, when, as soon as possible, the samples were kept in Styrofoam and taken to the Laboratory of Chemistry and Biology of the Universidade Federal do Maranhão - UFMA in Grajaú, for them to be submitted to the microbiological and physical-chemical analyses.

The methodology used for the determination of the physical-chemical parameters followed the empirical investigation method model, based on experiments to test, manipulate and control some variables of the study already tested in laboratory.

\subsection{Physical-Chemical Analyses}

During the physical-chemical tests, it was analyzed: Total Alkalinity, Chlorides, Total Hardness, pH, Iron, Ammonia, Chlorine, Consumed Oxygen, Water's Turbidity and Color. In the microbiological test: Total Coliforms and Thermotolerant Coliforms. For the physical-chemical analyses, the alfa kit probability kit was used.

\subsection{Microbiological Analyses}

During the microbiological stage, the MLN (Most Likely Number of Total and Thermotolerants Coliforms) in water was determined. This process was conducted three times and the first three tubes of each sample contained double concentrated broth.

The Presumptive stage consisted in inoculating determined volume of sample in series of tubes containing Lactose Broth (LB), where the lactose is utilized as source of carbon. Right after the inoculation, the tubes were incubated in growth greenhouse at a temperature of $35^{\circ} \mathrm{C}$ for a period between $24-48$ hours. The acidification with production of gases inside the tubes of Durhan results in positive tubes for presence of bacteria from the Coliforms group.

The Confirmative stage consisted in transferring each culture that reached positive results for the presumptive test to tubes containing Brilliant Green Bile Broth 2\% (BGBB), with the help of the platinum handle, making two transfers for each tube. Right after that, the tubes with $\mathrm{BGBB}$ were incubated in growth greenhouse also at a temperature of $35^{\circ} \mathrm{C}$ for a period between 24-48 hours. The Brilliant Green Broth has two microbiota's growth inhibiters, which are the bile salts and brilliant green that is also the only carbohydrate. This way, the fermentation of the lactose is the confirmative proof of the presence of bacteria from the Total Coliforms group that resulted in the formation of gas and the turbidity of the sample.

For the determination of Fecal and Thermotolerants Coliforms, it was taken as base the transference of each culture that reached positive result for total coliforms in the Brilliant Green Broth to tubes containing E.C. Broth that right after will be incubated for 24 hours at $45^{\circ} \mathrm{C}$ in water bath. The formation of gas and the turbidity of the means represent positive result.

Right after these processes, the positive cultures for E.C. Broth were peaked to plates containing EMB Agar and plates containing MacConkey Agar, with the help of the platinum handle. Then they were incubated at $35^{\circ} \mathrm{C}$ for $24-48$ hours and the growth of the colony was verified.

After this process, it has started the preparing and coloration of the bacteriological plates. After prepared, the plates were observed by optic microscopy with the objective lens of $40 \mathrm{X}$ and 100X for the observation and analyses of the following aspects: color (the positive gram are the ones that appear blue or violet and negative gram appear in red), format (the bacillus are in format of stick and the coccus are round) and arrange of the bacteria present in this sample.

\section{Results and Discussion}

The results that were obtained for the samples tasted on the five spots are represented on the table 01. 
Table 01-Physical-chemical parameters of the analyzed spots.

\begin{tabular}{|c|c|c|c|c|c|c|}
\hline Physical-chemical Parameters & $A 1$ & $A 2$ & $A 3$ & $A 4$ & $A 5$ & Limite \\
\hline Total Alkalinity $\left(\mathrm{CaCO}_{3} \mathrm{mg} / \mathrm{L}^{-1}\right)$ & 80 & 80 & 80 & 170 & 150 & $* * *$ \\
\hline Chloride $\left(\mathrm{Cl}^{-} \mathrm{mg} / \mathrm{L}^{-1}\right)$ & 30 & 30 & 30 & 110 & 110 & $250 \mathrm{mg} / \mathrm{L}$ \\
\hline Total Hardness $\left(\mathrm{CaCO}_{3} \mathrm{mg} / \mathrm{L}^{-1}\right)$ & 40 & 40 & 40 & 190 & 210 & $500 \mathrm{mg} / \mathrm{L}$ \\
\hline Ammonia & 0,25 & 0,25 & 0,25 & 0,25 & 0,25 & $1,5 \mathrm{mg} / \mathrm{L}$ \\
\hline Free Chlorine & 0,10 & 0,10 & 0,10 & 0,10 & 0,10 & $2 m g / L$ \\
\hline Iron & 0,25 & 0,25 & 0,25 & 0,25 & 0,25 & $0,3 \mathrm{ppm}$ \\
\hline$p H$ & 8 & 8 & 8 & 8 & 8 & $6-9$ \\
\hline Turbidity N.T.U. & 5 & 5 & 5 & 5 & 5 & $5 u T$ \\
\hline
\end{tabular}

Picture 01- Physical-chemical parameter of Sample A, B, C, D and E

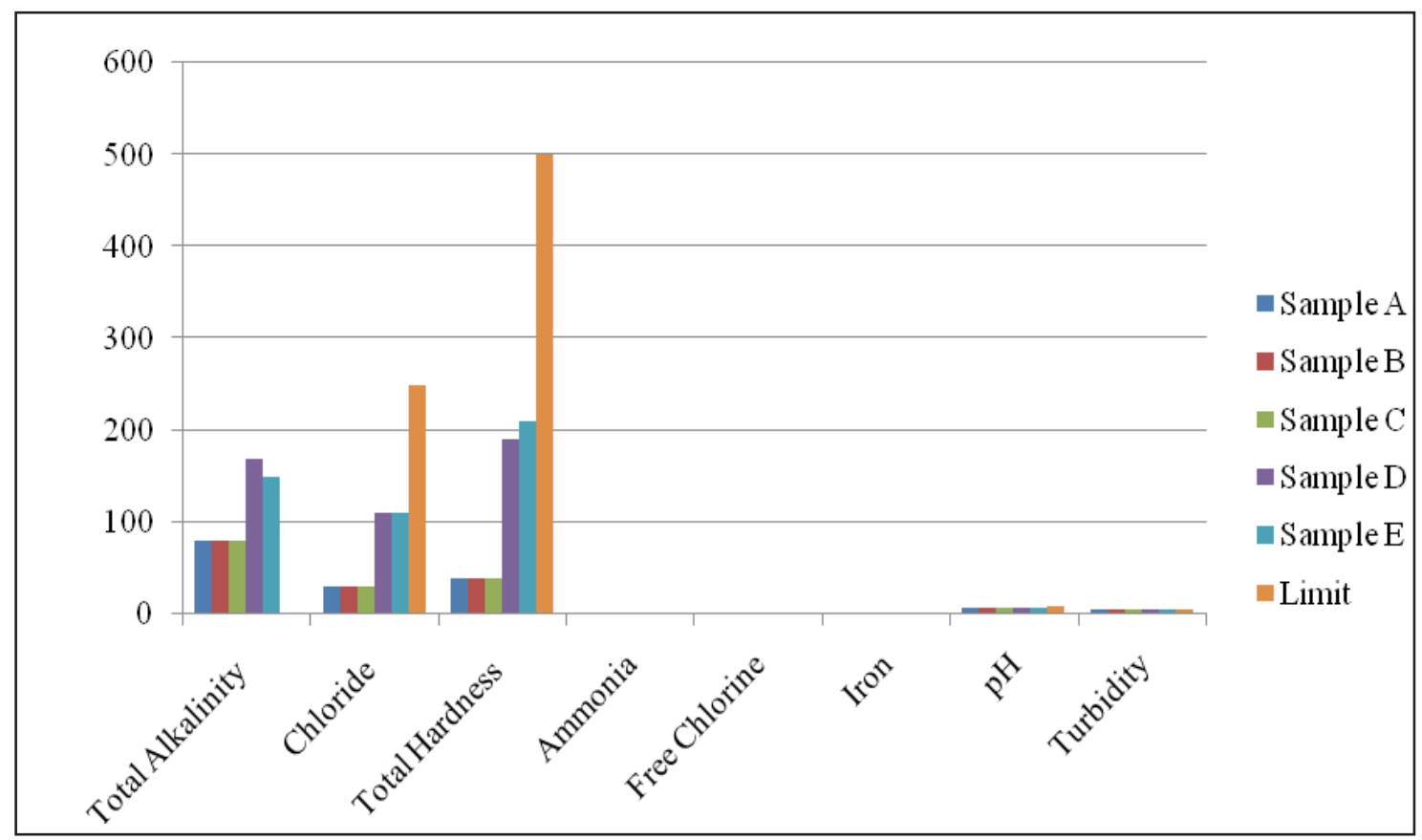

For the Alkalinity parameter, the results show values that vary between $80 \mathrm{mg} / \mathrm{L}$ and $170 \mathrm{mg} / \mathrm{L}$. There is no standard stablished for this parameter, however, when in high concentration, it is possible for this to turn the water bitterer.

The Total Alkalinity of water is the concentration of hydroxides, carbonates and bicarbonates that are expressed in Calcium Carbonate. It measures the capacity of the water to neutralize acids (BRASIL, 2009). According to Batista (2007), the elevated alkalinity is resulting from limestone rocks, this way, the water that passes through them acquire this characteristic.

The values for alkalinity can be explained by the fact of the plaster liberate $\mathrm{Ca}^{2+}$ and $\mathrm{SO}_{4}^{2-}$ ions that alter the alkalinity of the soil and contaminate the water tables (FARIAS, LORENA, 2010). According to Rabelo (2014), Grajaú-MA is a county of the state of Maranhão in which exists the second largest plaster polo of Brazil. About 200 thousand tons of calcined plaster are produced each year in Grajaú, as well as 18 million unities of plasterboards, beyond other products as the Agricultural Plaster and Calcium Sulfate. 
For the Chlorides parameter, the results present values that vary between $30 \mathrm{mg} / \mathrm{L}$ and $110 \mathrm{mg} / \mathrm{L}$. When talking about water quality regarded to Chlorides, it is important to know if this value keeps constant, since it does not exceed $600 \mathrm{mg} / \mathrm{L}$, because, according the World Health Organization (WHO), this value is considered the maximum admissible for public supply (SOUSA, 2001). This way, the values found fit the limit permitted by law.

For the Total Hardness parameter, the results show values that vary between $40 \mathrm{mg} / \mathrm{L}$ to $210 \mathrm{mg} / \mathrm{L}$.

The ordinance number 2914/11 from the Health Ministry establishes for hardness the ratio of $500 \mathrm{mg} / \mathrm{L}_{\text {in }}$ terms of CaCO ${ }^{3}$ as the maximum admissible value for potable water. The water is considered hard when the total hardness keeps between 100 $\mathrm{mg} / \mathrm{L}$ and $200 \mathrm{mg} / \mathrm{L}$ of concentration of $\mathrm{CACO}^{3}$. Above that, the water is considered very hard. Hard water could facilitate the appearance of kidney's diseases, cardiac problems and arterial hypertension (ABDALLA et al., 2010).

For the Ammonia parameter, the results show equal values for all samples that is $0,25 \mathrm{mg} / \mathrm{L}$, which is below permitted by law. In Brazil, the ordinance 2914/11, from Health Ministry establishes an acceptable standard for consumption of 1,5 mg/L ${ }^{-1}$ for non-ionizable ammonia $\left(\mathrm{NH}^{3}\right)$.

The ammonia can be naturally found in superficial or underground water as result of biota's excretions, water's Nitrogen gas reduction by microorganisms or by gases exchanges with the atmosphere. However, its concentration usually keeps at low levels, because of its easy absorption by the soil and others (REIS. MENDONÇA, 2009).

For the parameter of Free Chlorine, all the results show values equal to $0,10 \mathrm{mg} / \mathrm{L}$, the minimum existent in the comparative board of the probability kit utilized. This way, it can be observed that this values are below allowed by law, which are 0,2 $\mathrm{mg} / \mathrm{L}$ for minimum and $2 \mathrm{mg} / \mathrm{L}$ for maximum.

Nonetheless, because it is not treated, it is necessary to add sodium hypochlorite for its disinfection (NUNES, SIMOES, OLIVEIRA, 2010).

In all of the sources of water, Iron is usually found. When its values are above $0,5 \mathrm{ppm}$, it affects the color, smell and even the taste of the water. This way, it's important that the dissolved iron content in the water that is delivered to the population keeps low, ensuring the acceptation of the consumers (PICANÇO, LOPES AND SOUSA, 2002).

In Brazil, the ordinance 2914/11 of the Health Ministry establishes an acceptable standard for consumption of 0,3 ppm. The results obtained in this research for this parameter show the value of $0,25 \mathrm{ppm}$ for all of the samples, which means it is below permitted by law.

For the $\mathrm{pH}$ parameter, the results show the value 8 for all of the samples, which is permitted by law that determine the $\mathrm{pH}$ to keep between 6 and 9,5. The $\mathrm{pH}$ is an index that characterize the acidity or alkalinity degree of some environment. The main factors that determine the water's $\mathrm{pH}$ are the dissolved carbon dioxide and the alkalinity.

On the results of the Turbidity parameters, all of the samples showed values equal to 5uT, which means that the analyzed water fits the parameters stablished for potability. The maximum value allowed by the standard for the turbidity of disinfected underground water is of 5,0uT (BARCELLOS et al., 2006; PEZENTE, 2009).

For the parameter of Consumed Oxygen, all of the samples showed values above of the maximum of $5 \mathrm{mg} / \mathrm{L}$ that the kit reaches. According to Corcóvia, Celligoi (2012), there is not any well's water that obtain, for this parameter, quantities under $5 \mathrm{mg} / \mathrm{L}$. This way, the water that were analyzed on this research matches the values allowed by the actual laws.

The results of the microbiological tests of the samples collected in five spots are expressed in the Table 06.

Table 06 - Fecal Coliforms (FC) and Total Coliforms (TC) indexes

\begin{tabular}{c|c|c|c|c|c}
\hline Sample A & Sample B & Sample C & Sample D & Sample E & LIMIT \\
\hline$>1100$ & $>1100$ & 35 & $>1100$ & $>1100$ & Absence para $100 \mathrm{~mL}$ \\
\hline
\end{tabular}

When comparing the MLN/100 ml indexes obtained with the samples of the five spots, the presence of fecal coliforms is noticed in all of the spots and four of them show values that represents 2400 fecal coliforms for 100 ml, which is the maximum value established by the ordinance $2914 / 11$ for potability.

The underground water is usually potable and, because of that, dispense previous treatment, as it naturally passes by filtration processes of the soil that lead to its purification during its percolation, turning itself into a great quality water source, making it possible to be explored for human consume. However, bad quality underground water is possible to be found, due to some sources of contamination, for instance: domestic waste, septic tank, slurry coming from landfills, that contaminate water tables with pathogenic microorganisms (PORTO et al., 2011).

The growingcould be noticed on plates containing EMB Agar (Picture 02), which is a selective mean used for isolate and differ gram-negatives of the Enterobacteriaceaefamily. According Tortora, Funk and Case (2012), all of this family's members are oxidase-negative and its members are from the Escherichia, Enterobacter, Shigella, Citrobacter and Salmonella family. Escherichia, Enterobacter and Citrobcter, that ferment lactose to produce acid and gases, they can be differed from Salmonela and Shigella, that does not. 
Picture 02 - Growing on plates with EMB Agar

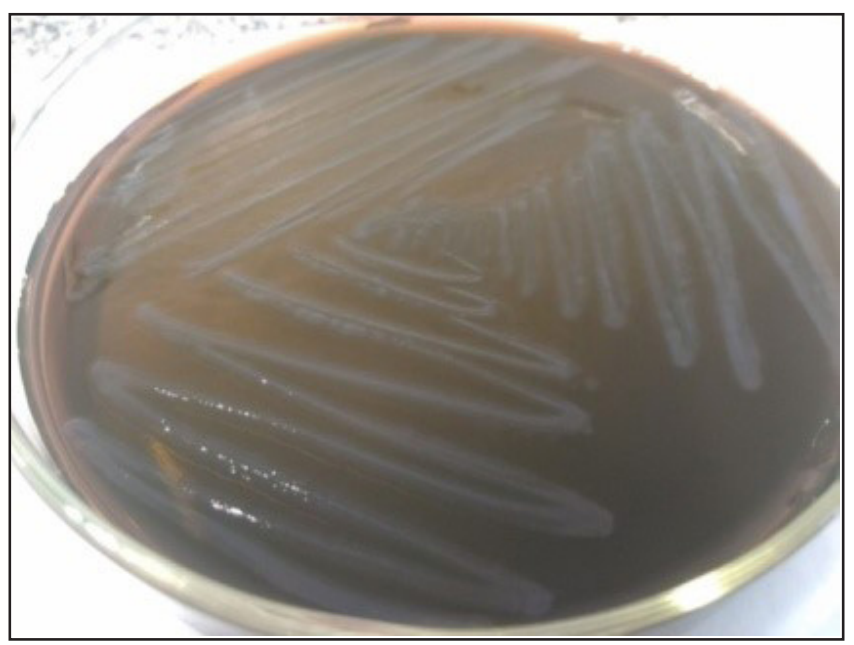

Picture 03 - Growing on plates with MacConkey Agar

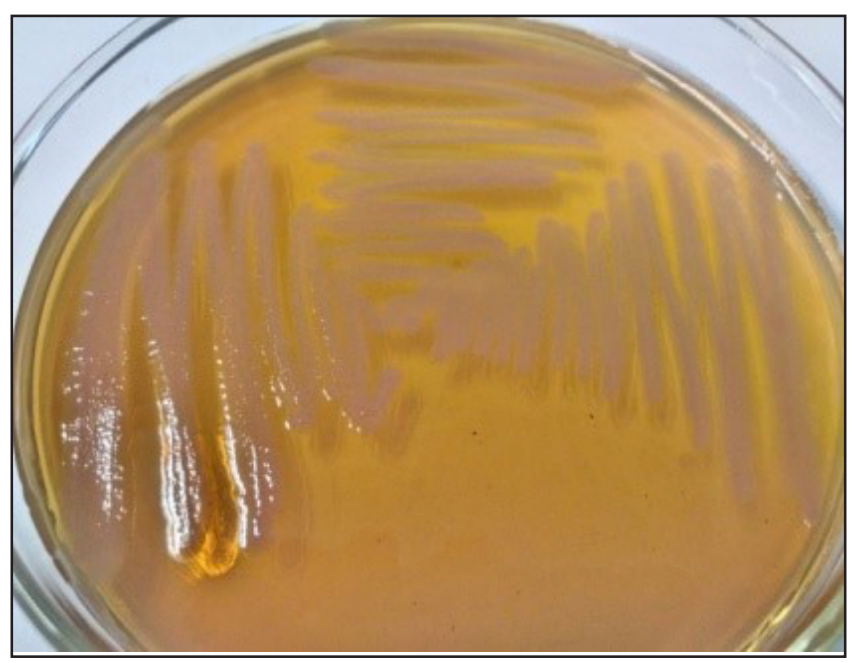

Picture 04 - Growing on plates with SS Agar

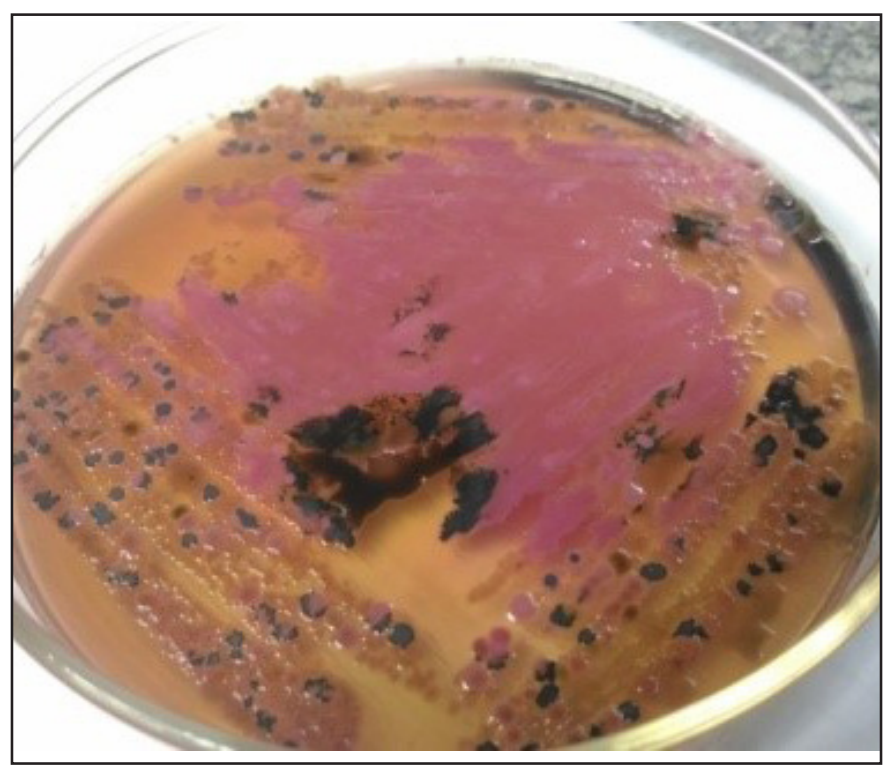


Due to the slow infiltration and biological, physical and chemical processes that occur in soil, underground water are naturally more protected from pollution. However, some factors can contribute for its contamination, for instance: depositing of solid waste on soil; sewer and septic tanks; agricultural activities; mining; leakage of toxic substances; cemetery; descendent vertical filtering; natural contamination; abandonment or misconstruction of wells (BRASIL, 2007).

\section{Final Considerations}

The results obtained on this analysis by the microbiological and physical-chemical tests show that the samples of underground water from five specific spots do not match the legislation, because they do not attend to the potability standards.

With this work, it was possible to make important and necessary observations about the quality of the water, specially the underground one. This way, it is important to notice standards that deviate from the ideal of consumption of the underground water, because this can lead to health issues for the county's population.

Because of this fact, it is really relevant that public policies intervene, making new analyses, mainly microbiological and biochemical tests, looking for analyzing water's quality and then adopting measures that make possible a proper treatment for this water that is used by local communities.

\section{References}

ABDALLA K V P, CAVALCANTE P R S, NETO J P C, BARBIERI R, NETO M C M A. Avaliação da Dureza e das Concentrações de Cálcio e Magnésio em Águas Subterrâneas da Zona Urbana e Rural do Município de Rosário-MA. Águas Subterrâneas. 2010(1): 1-11.

ALVES M N, MOLINA A G, SANCHEZ P S Exame Microbiológico da Água. São Paulo: Companhia de Tecnologia de Saneamento Ambiental; 1992.

BARRELL R, BENTON C, BOYD P, CARTWRIGHT R, CHADA C, COLBOURNE J, COLE S, COLLEY A, DRURY D, GODFREE A, HUNTER P, LEE J, MACHRAY P, NICHOLS G, SARTORY D, SELLWOOD J, WATKINS J. The microbiology of drinking water: water quality and publiche alth. Methods for the Examination of Waters and Associated Materials. Environment Agency, 2002.

BATISTA M H S, INTERAÇÃO ENTRE ÁGUAS MINERAIS DE ITAPARICA E O AQÜÍFERO PERIFÉRICO [monography]. Salvador: Departamento de Geologial Universidade Federal da Bahia; 2007.

BRASIL, Fundação Nacional de Saúde (FUNASA). Manual prático de análise de água. 3ª ed. rev. - Brasília: Funasa, 2009.

BRASIL, Ministério do Meio Ambiente (MMA). Águas Subterrâneas um recurso a ser conhecido e protegido. Brasília: ASSOCIAÇÃO BRASILEIRA DE ÁGUAS SUBTERRÂNEAS PETROBRAS, 2007.

BRASIL. Fundação Nacional de Saúde (FUNASA). Manual de saneamento. 3. ed. Brasília: Fundação Nacional de Saúde, 2007. Disponível em:

BRASIL. Presidência da República. Portaria nº 2914 de 12 de dezembro de 2011. Controle de vigilância da qualidade da água para consumo humano e seu padrão de potabilidade. Brasília: Ministério da Saúde, 2011.

BRASIL. Presidência da República. Resolução no 396 de 3 de abril de 2008. Classificação e diretrizes ambientais para o enquadramento das águas subterrâneas e dá outras providências Brasília: Conselho Nacional do Meio Ambiente, 2008.

CELLIGOI A. Considerações sobre análises químicas de águas subterrâneas. Geografia, 1999;8(1):91-97.

CORCÓVIA J A, CELLIGOI A. AVALIAÇÃO PRELIMINAR DA QUALIDADE DA ÁGUA SUBTERRÂNEA NO MUNICÍPIO DE IBIPORÃ-PR. REA - Revista de estudos ambientais. 2012;14(2):39-48.

FREIRE A. M. Reformas curriculares em ciências e o ensino por investigação. Actas do XIII Encontro Nacional de Educação em Ciências, Castelo Branco, 2009. Disponível em: < https://repositorio.ufrn.br/jspui/ bitstream/123456789/21882/1/MariaKamyllaESilvaXavierDeAlmeida_DISSERT.pdf>. Acesso em: 11 de jun. de 2017. 
HELLER L. 1998. Saneamento e saúde (Saneamiento y Salud). Washington, D.C.: CEPIS/OPS.

NASCIMENTO F J F, PIMENTEL L L. REAPROVEITAMENTO DE RESÍDUO DE GESSO. In: Anais do 13ํㅡ든 Nacional do Ambiente Construído [Internet]; 2010 outubro 6 a 8; Canelas, Brasil. 2010. Available from: www.infohab.org. br/entac2014/2010/arquivos/287.pdf.

NUNES T C G., SIMÕES T S G, OLIVEIRA V P S. AVALIAÇÃO DE PARÂMETROS FÍSICO-QUÍMICOS DAS ÁGUAS SUBTERRÂNEAS NOS DISTRITOS DE CAMPOS DOS GOYTACAZES/RJ. In: Anais do 2ํㅡㄴ Congresso Fluminense de Iniciação Científica e Tecnológica [Internet]; 2010 junho 7 a 10; Campos dos Goytacazes, Brasil. 2010.

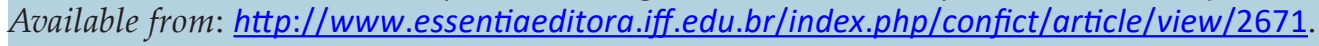

PAULA V L. Desenvolvimento e otimização de tecnologias de tratamento de águas para abastecimento público, que estejam poluídas com microrganismos, toxinas e microcontaminantes. Programa de Pesquisas em Saneamento Básico - PROSAB Edital 05, Departamento de Engenharia Sanitária e Ambiental da Escola de Engenharia da Universidade Federal de Minas Gerais. 2009.

PICANÇO F E L, LOPES E C S, SOUZA E. FATORES RESPONSÁVEIS PELA OCORRÊNCIA DE FERRO EM ÁGUAS SUBTERRÂNEAS DA REGIÃO METROPOLITANA DE BELÉM/PA. Águas Subterrâneas. 2002(1): 1-17.

PORTO M A L, OLIVEIRA A M, FAI A E C, STAMFORD T L M. Coliformes em água de abastecimento de lojas fast-food da Região Metropolitana de Recife (PE, Brasil). Ciência \& Saúde Coletiva. 2011;16(5):2653-2658.

REIS J A T, MENDONÇA A S F. Análise técnica dos novos padrões brasileiros para amônia em efluentes e corpos d'água. Eng Sanit Ambient. 2009;14(3):353-362.

TORTORA, G. J. Microbiologia. Porto Alegre : Artmed, 2012. 